\title{
原算論文
}

\section{大阪市における内水汇濫頻発区域の 分布とその特性}

\author{
中口 幸太 1 ${ }^{\dagger}$ 小森大輔 2) 井上 亮 3） 風間 聡 4） \\ 1) 東北大学大学院工学研究科 \\ （９９80-8579 宮城県仙台市青葉区荒巻字青葉 6-6-6） \\ 2) 東北大学大学院環境科学研究科 \\ （干980-8579 宮城県仙台市青葉区荒巻字青葉 6-6-6） \\ 3) 東北大学大学院情報科学研究科 \\ ( ₹ 980-8579 宮城県仙台市青葉区荒巻字青葉 6-6-6) \\ 4) 東北大学大学院工学研究科 \\ （９９80-8579 宮城県仙台市青葉区荒巻字青葉 6-6-6） \\ †連絡先著者（Corresponding Author）E-mail : kouta.nakaguchi.s1@dc.tohoku.ac.jp
}

\begin{abstract}
大阪府大阪市を対象として過去の浸水実績から内水汇濫の特性を解明することを目的とした，過去 20 年間の浸水 実績を記録した水害区域図をGISデータベース化し，内水氾濫が過去複数回発生している “内水氾濫頻発区域”を 抽出した，次に，“内水氾濫頻発区域”のもつ特性を解析した，解析の結果，地形的に集水が容易な “窪地”では優 先的に下水道の整備が行われており，抽出された内水汇濫頻発区域は“窪地”よりも“平地”に分布する傾向があ ることが明らかとなった，さらに，内水氾濫頻発区域の特性として，周囲よりも傾斜，標高が小さい地点に分布す る傾向があること, 道路や鉄道などの地表面流及び下水道を分断する構造物付近に分布する傾向があること, 付近 に小・中学校が位置しているケースが多いことが定量的に示された.
\end{abstract}

キーワード : 内水氾濫, 大都市圏, 水害区域図, GIS

\section{I 。序論}

日本の都市の多くは, 大河川の下流部の低平地に 位置していることや，他国と比較して河川勾配が急 であることから，水竾害を受けやすいという特性を 有している（平井ら，1996）。特に，雨水を河川の本 川・支川等に排水できないことに起因して堤内地に 雨水が停滞する現象である内水汇濫は，近年都市部 を中心に甚大な被害をもたらしている。水害統計調 查より，2006年から 2013 年に扮ける一般資産被害額 に占める内水汇濫による被害額の割合が, 全国では $42.0 \%$ \% あるのに対し, 東京都で $63.0 \%$, 愛知県で $85.0 \%$, 大阪府で $96.5 \%$ と大都市で大きくなってい る。また，IPCCの評価報告書（IPCC, 2013）による と, 気候変動の多くのリスクは都市域に集中してお り, 近年の都市化に伴う不浸透域の拡大やゲリラ豪
雨の増加によって今後の都市部における内水汇濫り スクはさらに増加すると考えられる。

内水汇濫の対策として汇濫解析による浸水シミュ レーションが広く行われて招り（関根ら, 2015； Fernandes and Lutz, 2010), その結果をもとに作成し たハザードマップを公表している地方自治体もある (大阪市建設局, 2015). しかし, 内水汇濫の浸水シ ミュレーションは, ある地度限られた範囲で浸水域 推定を行う必要があり, 広域的に一律の基準で内水 氾濫発生メカニズムに関するパラメータを評価する ことが難しい点や（国土交通省, 2016), 微細な地形 の影響を評価することが難しい点などの課題がある (飯田ら, 2005). 一方, 大都市全域を対象として過 去の浸水実績から内水汇濫が頻発している区域（以 下, 内水汇濫頻発区域と呼ぶ）の分布を解明し, そ 
の特性を定量的に評価することで，浸水シミュレー ションでは考慮できない要素も含めた特性を把握す ることができると考えられる。

過去の浸水実績から内水汇濫の特性を求めた研究 として, 尾崎ら（2012）は2011年8月27日に大阪で 発生した豪雨時に内水汇濫で浸水した区域を対象 に, 内水汇濫脆弱地の特性を考察した。この研究よ り, 内水汇濫は窪地のように集水しやすい地点でな い場合でも，擁壁や建物等によって地表面流が阻害 されるような地点であれば内水氾濫脆弱地と成り得 ることが示唆された。しかし，この研究は特定の豪 雨で浸水した実績であり，この研究で示された内水 氾濫脆弱地の特性が, 内水氾濫頻発区域においても 当てはまるかは不明である。

内水氾濫頻発区域の特性に関しては多くの既往研 究がある。村山ら（1987），福嶋ら（1988）は水害 統計を用いて内水汇濫に脆弱な地域を選択し，内水 氾濫に脆弱となった過程を明らかにした。しかし， 水害統計は空間的最小スケールが市区町村単位であ るため，実際に浸水した地域を空間的に把握するこ とができず，市区町村単位よりも詳細なスケールで は内水氾濫に対して脆弱な地域を把握することがで きない，また，これらの研究は，各地域特有の歴史 的背景に焦点を当てた解析である，今後の治水政策 に適用させるためには，その土地固有の特性だけで なく，内水氾濫頻発区域が普遍的に持つ特性を解明 する必要がある。そのためには都市域全域といった 広いスケールで解析を行う必要があると考えられ る。しかし，大都市全域といった広いスケールに扮 ける内水汇濫頻発区域の分布は未だわかっていない，

外水汇濫が頻発している地域を空間的に抽出した 研究として, 梯ら（2014）は過去の浸水実績を記録 した水害区域図を用いることで全国の外水氾濫常襲 地を抽出し，その形成メカニズムを解明した.

そこで本研究では, 2006年から2013年に扔ける水 害被害額のうち内水氾濫による被害額の割合が最も 大きい大阪市を対象として，水害区域図を用いて内 水汇濫頻発区域を抽出し，その特性を解明すること を目的とした。

\section{II.内水汇濫頻発区域の抽出}

\section{1. 水害区域図}

水害区域図の例を図一1に示す，水害区域図は水 害統計調査の一環として水害発生の都度，各市区町

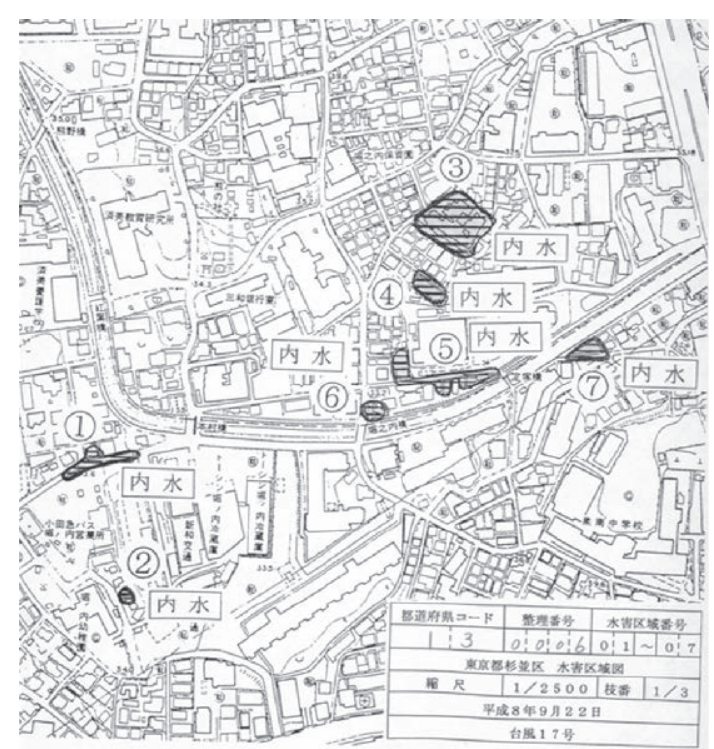

図-1 水害区域図の例

Fig. 1 Flood area map.

村が作成している地図である，水害区域図は，1つの 水害区域の面積が $1,000 \mathrm{~m}^{2}$ 以上または被害建物棟数 が 10 棟以上の場合に国土交通省によって指定された 作成要領（国土交通省, 2012）に従い作成される. 水害区域図には浸水区域の他に，水害種類，水害発 生日, 異常気象名等が記録されている. 水害種類に ついては, 破堤（記号：×）, 有堤部溢水（記号: ○), 無堤部溢水 $($ 記号： $\triangle$ ), 土石流・地すべり・ 急傾斜地崩壊（記号： $\square$ ), その他（「内水」「波浪」 等のように文字で記入）で分類される.1993年以降 の水害区域図は国土交通省に画像デー夕（pdf形式） で保存されている。 そのため, 浸水区域の位置や形 状を表すデジタルデータは作成されていない。この 理由によって，既往研究では広域スケールに打ける 内水汇濫に対する脆弱地の抽出を目的として水害区 域図を用いた事例はない.

本研究では, 対象地域とした大阪市に扔ける 1993 年〜 2012年の 20 年間分の水害区域図計 1069 枚を国 土交通省から入手し, 内水汇濫頻発区域を抽出した.

\section{2. 内水氾濫頻発区域の抽出手順}

前節で述べたように，水害区域図はpdf形式で保 存されている画像データであるため, 直接解析に用 いることはできない。そこで，本研究では水害区域 図に記録されている情報を地理情報システム（以下， GIS と呼ぶ）データベース化することで解析を可能 
にした、はじめに，国土交通省から入手した水害区 域図 1,069 枚のうち, 内水氾濫による浸水区域が記 録された水害区域図計 155 枚を利用し, 記録されて いる浸水区域を水害の発生した年度ごとにポリゴン のシェープファイルで作成した。次に，内水汇濫頻 発区域として抽出するメッシュサイズでラスタデー タへと変換した。なおメッシュ内に少しでも内水汇 濫が発生した場合は，そのメッシュでは内水汇濫が 発生したものとした。作成した各年度のラスタデー 夕を重ね合わせ，各メッシュにおいて1993年から 2012 年の 20 年間で内水氾濫が発生した年数を求め た。水害区域図は市区町単位で作成されるが，行政 区域を越えて浸水域が記録されている水害区域図も 散見された。 そこで, 求めた数值は各メッシュにお いて内水汇濫が発生した年数とした。 よって, 同 メッシュにおいて同年に内水汇濫が複数回発生した 場合でも内水汇濫発生年数は 1 とした.

\section{3. 内水汇濫頻発区域の定義}

抽出するメッシュサイズを変化させた場合の内水 汇濫の発生年数と抽出区域数の関係を表一 1 に示す. 最大発生年数は $5 \sim 7$ 年であった.

抽出するメッシュサイズについて，メッシュサイ ズを小さくするほど微細な地形や周辺に位置する 個々の建造物等の詳細な要素と内水氾濫頻発区域の 関わりを知ることができる。本研究では, 内水汇濫 頻発区域の具体的な分布およびその特性を解明する ことを目的としているため, 抽出するメッシュサイ ズはある程度小さい方が適切である。しかしながら， 水害区域図作成及びGIS データベース化の作業時に 生じた最大で $50 \mathrm{~m}$ 程度の誤差を確認しており, メッ シュサイズを小さくしすぎた場合，明らかに同地点 で発生している浸水区域を別々に計算してしまい, 内水汇濫頻発区域を適切に抽出できない。そこで本 研究では, 抽出するメッシュサイズを $100 \mathrm{~m} \times 100$ mとした。

表-1 メッシュサイズと抽出区域数の関係

Table 1 Relations of mesh size and number of the frequent inland inundation areas.

\begin{tabular}{|c|c|c|c|c|c|c|}
\hline \multirow{2}{*}{$\begin{array}{c}\text { 内水氾濫 } \\
\text { 発生年数 } \\
\text { (年) }\end{array}$} & \multicolumn{6}{|c|}{ メッシュサイズ } \\
\hline & $10 \mathrm{~m}$ & $30 \mathrm{~m}$ & $50 \mathrm{~m}$ & $100 \mathrm{~m}$ & $200 \mathrm{~m}$ & $400 \mathrm{~m}$ \\
\hline 1 & 38,687 & 7,648 & 4,089 & 1,879 & 898 & 337 \\
\hline 2 & 3,820 & 1,082 & 692 & 462 & 323 & 210 \\
\hline 3 & 645 & 261 & 189 & 138 & 116 & 99 \\
\hline 4 & 70 & 36 & 45 & 49 & 42 & 45 \\
\hline 5 & 4 & 8 & 10 & 20 & 23 & 18 \\
\hline 6 & & 1 & & 1 & 4 & 5 \\
\hline 7 & & & & & & 2 \\
\hline
\end{tabular}

また, 内水氾濫頻発区域とする基準発生年数につ いて, 基準年数が小さいと内水氾濫頻発区域に適当 でない区域を抽出してしまう。しかし, 基準が大き いと抽出される区域数が少なくなり, 内水氾濫頻発 区域が普遍的に有する特徵を解明するために十分な 区域数を得ることができない，そこで本研究では， 内水汇濫の最大発生年数の半分以上を目安とし, 1993 年から 2012 年の 20 年間で内水氾濫が 4 年以上 発生した区域を内水汇濫頻発区域と定義した。

\section{4. 抽出結果}

前節で述べた定義に従い, 内水汇濫頻発区域を抽 出した結果を図一2に示す。結果として, 70 区域の内 水汇濫頻発区域が抽出された。 また, 内水氾濫頻発 区域の面積が都市の総面積に対して占める割合を求 めたところ, 0.34 \%であった。

\section{III. 内水汇濫頻発区域の特性}

\section{1. 地形的分類}

経験的に, 内水汇濫は地形的に水の溜まりやすい 地点に発生すると認知されている。野々村ら（2011） は香川県高松市の市街地を対象として, 解像度 $5 \mathrm{~m}$ の数值標高モデルから内水浸水の可能性がある箇所 を抽出した，浸水実績のある7箇所中 5 箇所が抽出 された箇所と一致していた。 そこで, 本研究では浸 水想定区域図作成に拈いても使用実績が多い二次元

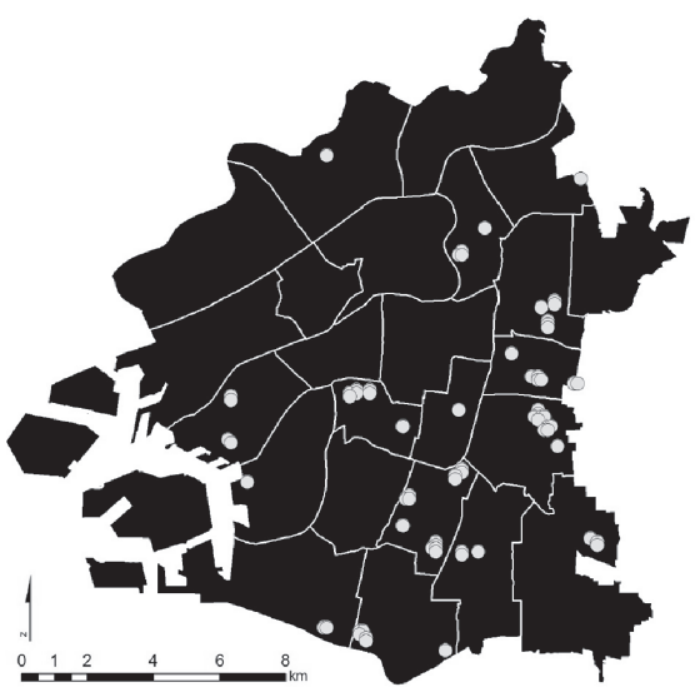

図 - 2 内水氾濫頻発区域の抽出結果 (白線は区境を示す)

Fig. 2 Distribution of inland inundation areas: white line shows the district boundary. 
不定流モデルを利用することで地形的に水が集まり 易い地点を算出し, 抽出した内水氾濫頻発区域が地 形的に水の集まりやすい地点に分布しているかを確 認した。二次元不定流モデルは秋間ら（2015）が使

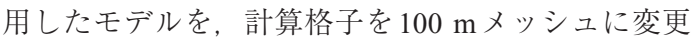
したものを使用した。 土地利用は国土数值情報によ る分類で $74.3 \%$ を占める建物用地, 降雨量を大阪市 における再現期間約 50 年極值降雨に相当する 250 $\mathrm{mm} / \mathrm{day}$ （風間ら, 2009）で一定として浸水深を算出 した．建築基準法より家屋の最低床高は $0.45 \mathrm{~m}$ と定 められている。そこで，家屋の床高を $0.45 \mathrm{~m}$ と仮定 し, 二次元不定流モデルより算出した浸水深が 0.45 $\mathrm{m}$ 以上の地域を, 地形的に水が集中しやすい“窪地” として定義し抽出した（図一3）。また，窪地でない 地域を“平地”と定義して内水氾濫頻発区域を分類 した結果，大阪市全域では“窪地”が総面積の 29.9 \%, “平地”が総面積の $70.1 \%$ \%゙った。また，内 水汇濫頻発区域の分布状況を求めたところ, “寉地” に 10 区域, “平地”に60区域分布していることがわ かった。

また，大阪市建設局から提供いただいた下水道台 帳より，大阪市全域と内水汇濫頻発区域の下水道の 整備状況を比較した。ここで，下水道の整備状況は 大阪市下水道局の方の助言から，単位面積当たりの ますの数及びマンホールの数に比例するものと仮定 した。結果を表一2に示す。ます・マンホールの密 度は，窪地ではそれぞれ3,338 個 $/ \mathrm{km}^{2}, 977$ 個 $/ \mathrm{km}^{2}$ で

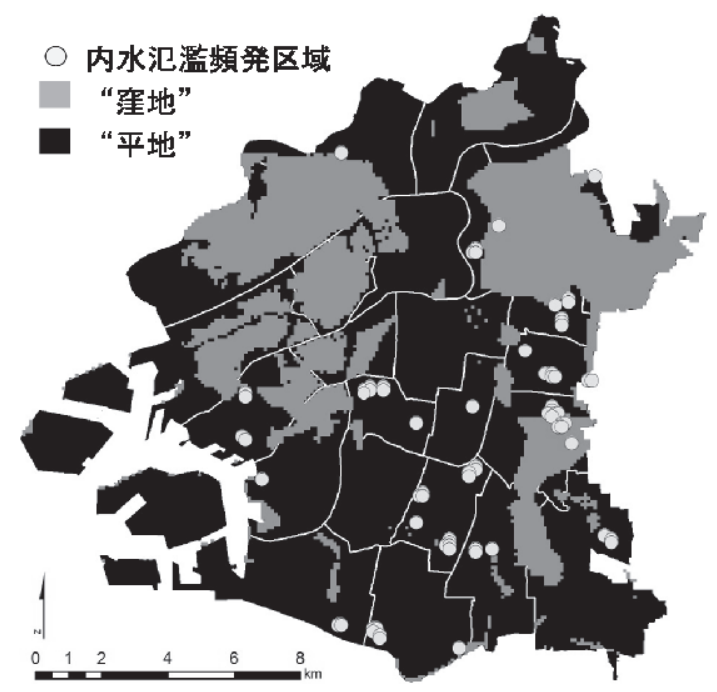

図 - 3 “窐地”と“平地”（白線は区境を示す）

Fig. 3 “Depression” and “plain” areas.
あるのに対し，平地ではそれぞれ2,541個 $/ \mathrm{km}^{2}, 797$ 個 $/ \mathrm{km}^{2}$ であった。 これより, 窪地では優先的に下水 道の整備が進められていることがわかった。また， 大阪市全域と内水汇濫頻発区域におけるます・マン ホールの密度を比較すると, “窪地”, “平地”に関 わらず内水氾濫頻発区域において密度が大きいこと がわかる。“平地”であるにも関わらず内水氾濫頻 発区域において下水道の整備が進められていること から, 地形的に浸水しにくい区域においても内水に 脆弱な区域が存在し，その要因には地形的な要因以 外の要因が関連していると考えられる。

\section{2. 傾斜・標高}

大阪市全域及び内水汇濫頻発区域の平均傾斜 ·平 均標高を求めた。デー夕は国土地理院の「基盤地図 情報 $5 \mathrm{~m}$ メッシュ」を $100 \mathrm{~m}$ メッシュに変換したも のを用いた。結果を図一 4 , 図一 5 に示す。平均傾斜 はそれぞれ $2.72 \%, 2.20 \%$ \%あり，平均標高はそれ ぞれ $3.59 \mathrm{~m}, 3.30 \mathrm{~m}$ であった。 また，大阪市全域にお ける平均傾斜よりも傾斜が小さい内水氾濫頻発区域 は58区域，大きい区域は12区域であり，大阪市全 域における平均標高よりも標高が小さい内水氾濫頻 発区域は49区域，大きい区域は21区域であった。

表-2 大阪市全域と内水氾濫頻発区域のます・マン ホールの数密度の比較

Table 2 Density of mass and sewer access throughout Osaka city and frequent inland inundation areas.

\begin{tabular}{c|c|c}
\hline \multirow{2}{*}{} & \multicolumn{2}{|c}{ ますの密度 $\left(\right.$ 個 $\left./ \mathrm{km}^{2}\right)$} \\
\cline { 2 - 3 } & 窪地 & 平地 \\
\hline 大阪市全域 & 3,338 & 2,541 \\
内水氾濫頻発区域 & 6,700 & 5,402 \\
\hline \multicolumn{2}{|c}{} \\
\hline \multicolumn{2}{|c}{} & マンホールの密度 $\left(\right.$ 個 $\left./ \mathrm{km}^{2}\right)$ \\
\cline { 2 - 3 } & 窪地 & 平地 \\
\hline 大阪市全域 & 977 & 797 \\
内水氾濫頻発区域 & 1,675 & 1,650 \\
\hline
\end{tabular}

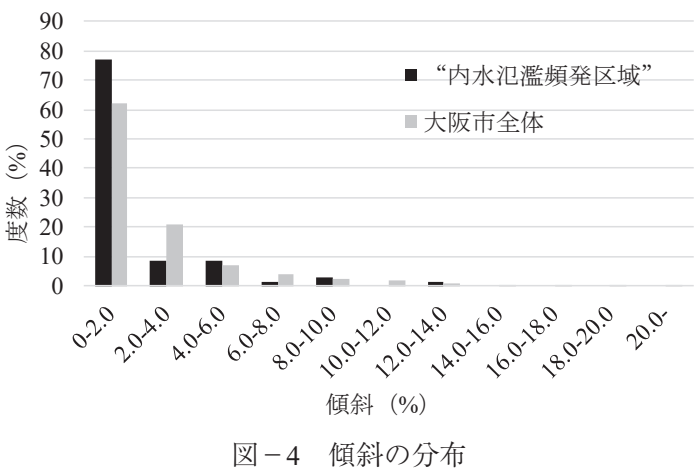

Fig. 4 Distribution of slope. 


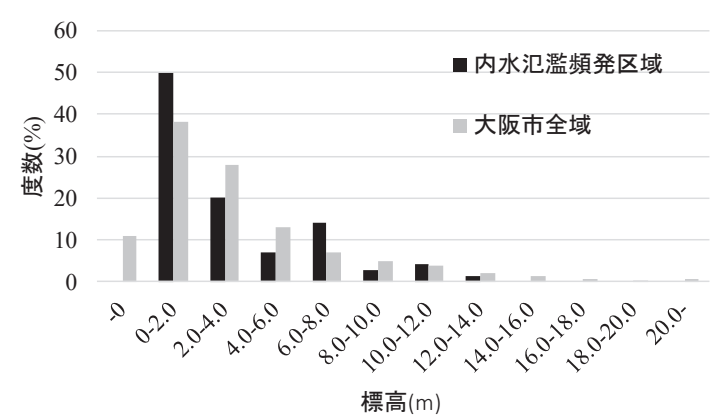

図 -5 標高の分布

Fig. 5 Distribution of height.

よって, 内水汇濫頻発区域は傾斜・標高ともに小さ い区域に分布する傾向があることがわかった．

\section{3. 支配構造物}

水の流れに影響を及ぼすと考えられる構造物が, 内水汇濫頻発区域拉よびその周辺においてどのよう に位置しているか検討した，水の流れに影響を及ぼ す構造物として, 下水道を分断する道路, 線路（地 下鉄, 高架を除く), 堤防, 1 辺 $100 \mathrm{~m}$ 以上の敷地を 持つ構造物を総称して支配構造物と定義した。ここ で，下水道を分断する道路とは，道路の中心直下に 下水管が埋設されているのではなく, 道路の両脇下 にそれぞれ下水管が埋設されている道路のことを指 す。これらの道路は中央分離带を有したり，片道複 車線のような道路幅が大きい道路であり，水の流れ に影響を及ぼすと考え本項での解析に含めた。

内水氾濫頻発区域を, 支配構造物の位置関係及び 支配構造物に対する傾斜方向の関係で分類した，分 類条件の概念図及び分類された区域の比率を図一6 に示す。ここで, 図一6 (a) - (h) は内水汇濫頻発区

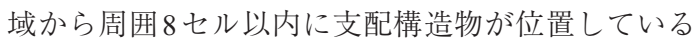
区域であり，図一6(i)-（j）はそうでない区域を意 味する。また，図一6 (h) は内水氾濫頻発区域の周 囲3方向に支配構造物が存在しており, 傾斜方向前 方に支配構造物が位置する区域を意味する。周囲3 方向に支配構造物が存在し, 傾斜方向前方に支配構 造物が位置していない区域は無かったため図一6に は示していない.

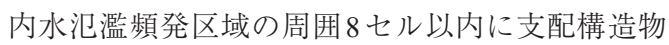
を含む区域は 63 区域，割合にして $90.0 \%$ であった。

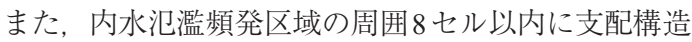
物がある区域の内，傾斜方向前方に支配構造物があ る区域（図一6破線枠内）の割合は $74.6 \%$ であった。

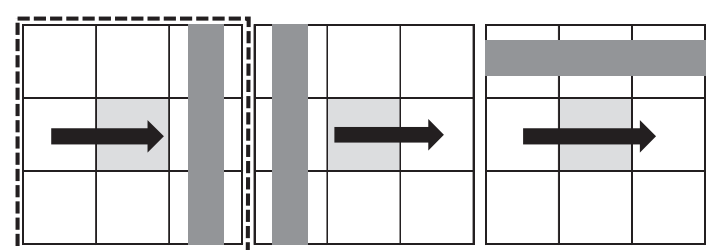

(a) $29 \%$

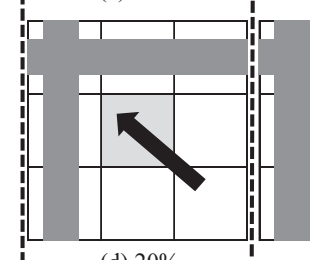

(d) $20 \%$

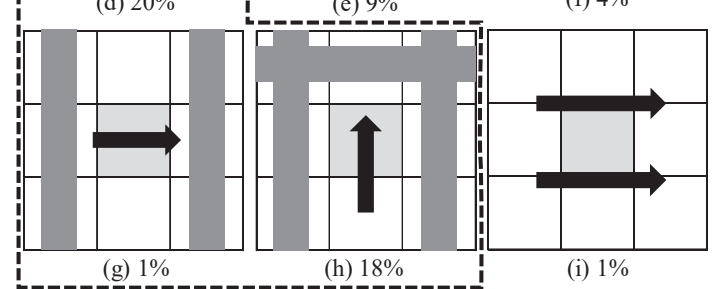

$\Rightarrow$ 傾斜方向

\section{内水氾濫頻発区域}

支配構造物 (b) $7 \%$

(c) $3 \%$

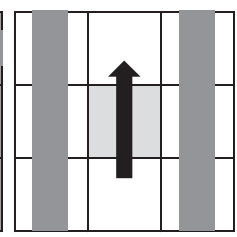

(f) $4 \%$

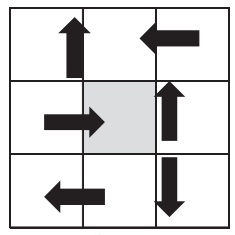

(j) $9 \%$
図 -6 支配構造物の位置及び傾斜方向による内水汇濫 頻発区域の分類結果（破線は傾斜方向前方に支 配構造物が位置するケース)

Fig. 6 Classification of frequent inland inundation areas by the position of the surrounding structure and flow direction.

\section{4. 学校}

村山（1987）は神奈川県川崎市を水害常襲地とし， 戦中期・高度経済成長期に公的機関が土地条件の悪 い川崎市に進出したことが水害常襲地を形勢した要 因であると指摘した。これは，公共性の高い施設は 必要性が高く, 財政的問題も加わり土地条件の悪い 地域へと進出したことによるものである。また，山 形県南陽市の赤湯自動車学校 (現在のマツキドライ ビングスクール赤湯校）は, 河川法の特例法によっ て, 公共性の高い施設として例外的に吉野川の河川 敷に建設された。この施設は, 吉野川の増水によっ て過去数回浸水して抢り, 水害リスクの高い区域に 位置しているといえる.

これらの事例のように，公共施設は水害等の災害 リスクが高い区域に位置する傾向があるのではない かと考え, 抽出された内水汇濫頻発区域と公共施設 
の関係に着目した。本研究では, 比較的数も多く, 位置データを入手し易いという理由から，小・中学 校（以下，学校と称す）と内水汇濫頻発区域の関係 について検討した。

国土数值情報（国土交通省）より，学校の位置 デー夕を取得し, 公立の小・中学校である441校を 抽出した。また，大阪市における小学校，中学校の 平均校地面積はそれぞれ9,695.85 $\mathrm{m}^{2}, 14,893.76 \mathrm{~m}^{2}$ で ある（大阪市, 2016）。これより，学校の敷地を 100 $\mathrm{m}$ 四方の正方形であると仮定した。内水汇濫頻発区 域及び大阪市全域における小・中学校（以下，学校 と称す）までの最短距離の分布を求めた。ここで, 大阪市全域における学校までの距離とは大阪市全域 を $100 \mathrm{~m}$ 四方のメッシュに区切り，各メッシュの辺 から学校の辺までの最短距離を指す。また，各メッ シュと学校の敷地が重なっている場合, 距離は $0 \mathrm{~m}$

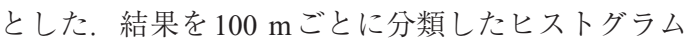
を図一7に示す。大阪市全域及び内水氾濫頻発区域

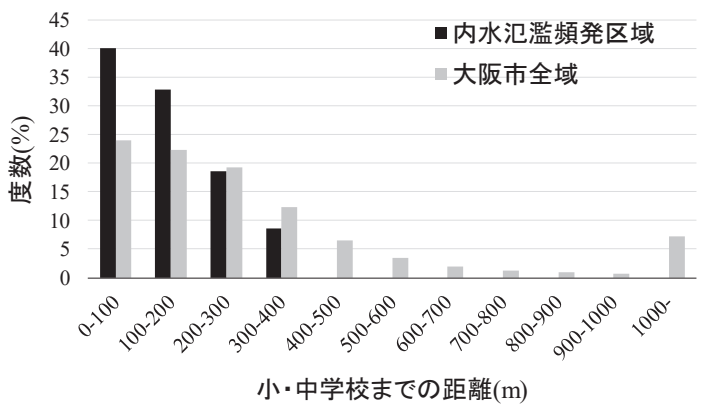

図-7 内水氾濫頻発区域および大阪市の各メッシュか ら小・中学校までの距離

Fig. 7 Distribution of distance to school.
から学校までの距離までの平均值はそれぞれ 348.7 $\mathrm{m}, 141.3 \mathrm{~m}$ であった。 また, 内水氾濫頻発区域の周 囲 $100 \mathrm{~m}$ 以内に学校が位置するケースが28 区域（40 \%）であり，内水氾濫頻発区域の付近に学校が位置 する傾向が示された。これは，村山（1987）が示し た水害常襲地およびその周辺が，公共施設と深い関 連があるということと一致する傾向である.

一例として，大阪市立茠田南小学校の設立前後の 状況を, 衛星画像を用いて比較した（図一8）。衛星 画像は国土地理院より取得した。荷田南小学校は 1969年に茠田小学校の児童数が増加したことにより 分校として設立された。図一8より，年を経るにつ れ都市部が拡大しており，水田として利用されてい た土地に小学校を建設したことがわかる。また，小 学校の敷地の約半分が貯水池を埋め立てた土地であ る. 水田・貯水池はどちらも重力を利用して水を溜 める施設であることから，水が集まりやすい，すな わち水害リスクの高い地点に位置するといえる。以 上のことから, 苅田南小学校は都市が拡大した結果 必要となり，何らかの理由で水害リスクの高い地点 に建設されたものであることが明らかとなった。

図ー7に示した結果および苅田南小学校を例にし て挙げた事例より，学校は水害リスクの高い地点に 建設される傾向があることが示唆された。

\section{IV。結論}

本研究では，水害区域図を用いることで日本を代 表する大都市である大阪府大阪市における内水汇濫 頻発区域の分布を明らかにした。抽出された内水氾
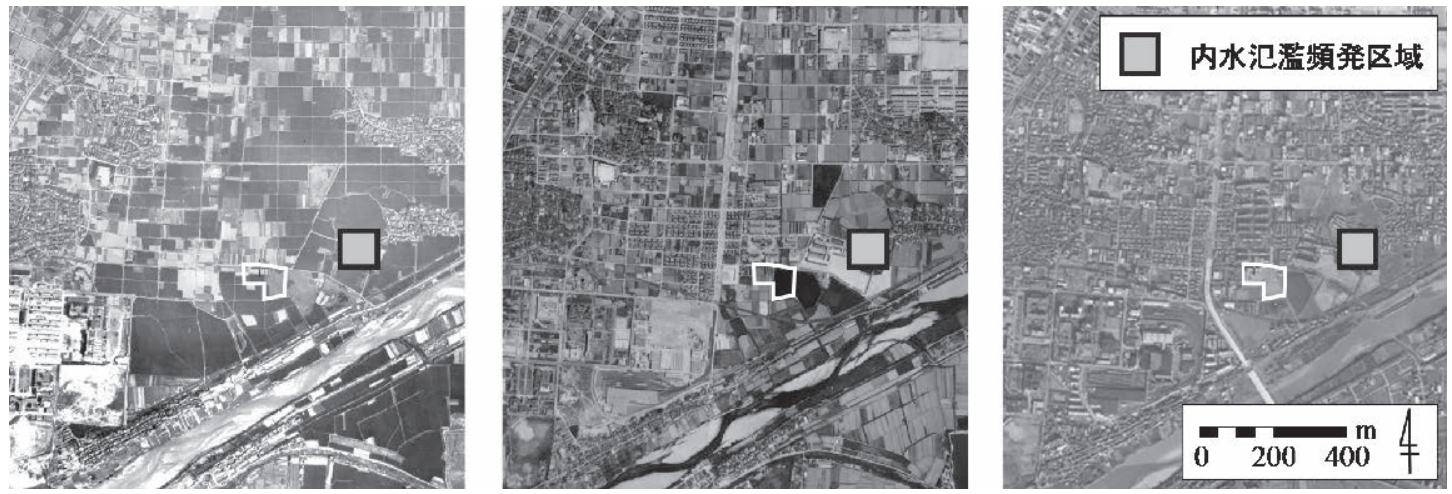

図 -8 茠田南小学校付近の 1945-1950 年（左）と 1961-1964 年（中）, 1974-1978 年（右）の状況（赤は内水汇濫 頻発区域, 白線は苅田南小学校の敷地を示す).

Fig. 8 Situation around Karita-minami junior high school at 1945-1950 (left), 1961-1964 (center) and 1974-1978 (right) : white line shows the Karita-minami junior high school area. 
濫頻発区域は 70 区域であり, 大阪市の総面積に対し て占める割合は $0.34 \%$ \%あった。また, 抽出された 内水汇濫頻発区域を様々な観点から解析した結果, 以下のことが明らかになった。

1）内水氾濫頻発区域は，地形的に水が集まり易い 窪地よりも平地に分布する傾向があり, 窪地で は優先的に下水道の整備が行われていた。

2）内水氾濫頻発区域は, 傾斜, 標高が小さい地点 に分布する傾向があった。

3）内水汇濫頻発区域の傾斜方向前方には，道路や 鉄道等をはじめとする支配構造物が位置する傾 向があった。

4）内水汇濫頻発区域は学校に近い位置に分布する 傾向があった.

本研究で示された内水汇濫頻発区域の特性は, 既 往研究（尾崎ら, 2012 ; 村山ら, 1987）で示された内 容と一致する点が見受けられた。 よって, 内水汇濫 頻発区域の特性を解析したことで, 既往研究で示さ れた結果を定量的に裏付けることができたといえ る。また, 本研究では大阪市全域を対象として内水 氾濫頻発区域の抽出拉よびその特性評価を行った. 本研究で示された内水汇濫頻発区域の分布およびそ の特性は, 大阪市全域に対し過去の浸水実績から一 律の基準で定量的に評価した結果であるため, 浸水 シミュレーションによる浸水域推定の検証を行う際 に重要な指標となると考えられる.

また，内水汇濫対策のひとつとしてハザードマッ プが作成されるが, 信頼性の高いハザードマップを 作成するためには高精度の浸水シミュレーションを 行う必要がある。高精度の浸水シミュレーションを 行うためには, 標高データの他に地下街や地下鉄等 を考慮するための正確な地下データや下水道データ 等が必要であり, 十分にデータが整備されていない 地域では高精度の浸水シミュレーションを行うこと が難しい. 本研究で示された傾向が他地域の内水汇 濫頻発区域掞いても当てはまるか今後検討すること で, 内水汇濫頻発区域が普遍的に有する傾向を定量 的に評価できると考えられる。内水汇濫頻発区域が 普遍的に有する傾向を定量的に示すことで, 浸水シ ミュレーションに必要なデータが十分に整備されて いない地域に扔ける内水汇濫対策を講じる際に有効 な指標になると考えられる.

\section{謝辞}

本研究の一部は, (公財) 旭硝子財団平成 26 年度
研究奨励助成, 環境省環境研究総合推進費 (S-14), 気候変動適応技術社会実装プログラム（SI-CAT）， 公益財団法人能村膜構造技術振興財団の支援により 実施された、水害区域図は国土交通省水管理・国土 保全局河川計画課より提供いただいた。大阪市の下 水道台帳は大阪市建設局下水道河川課より提供いた だいた。また, 梅松理美さんには本研究で利用した データを整備していただいた。ここに記し，感謝の 意を表す.

\section{引用文献}

秋間将宏・風間 聡・小森大輔·多田 毅 2015 : 適応策推定のため の洪水·高潮複合災害の相対的脆弱性. 水文・水資源学会2015 年度研究発表会要旨集, Vol.28, 116-117.

Fernandes, D.S., Lutz, M.A. 2010. Urban flood hazard zoning in Tucuman Province, Argentina, using GIS and multicriteria decision analysis. Engineering Geology, Vol ume 111, Issues 1-4: $90-98$.

福嶋依子 1988: 都市型水害常襲地域の形成機構-埼玉県越谷市 を事例として-. お茶の水地理, 29, 43-46.

平井真砂郎・道上正規・檜谷 治 1996: 都市域における浸水汇濫 解析に関する基礎的研究. 水工学論文集, 40, 405-412.

飯田進史·島田立季·渡辺 毅. 神岡誠司. 谷岡 康 2005: 降雨分 布を用いた中小河川及び内水危険箇所の即時評定方法の検討. 河川技術論文集, Vol.11, 199-202.

梯 滋郎·中村晋一郎・沖 大幹・沖 一雄 2014: 日本の水害常襲地 の分布とその特性. 土木学会論文集B1 (水工学), 70 (4), I_1489-I_1494.

環境省 :IPCC 第5次評価報告書の概要-第2作業部会 (影響, 適 応, 及び脆弱性) -, http://www.env.go.jp/earth/ipcc/5th/pdf/ ar5_wg2_overview_presentation.pdf. (参照:2017/01/16).

風間 聡·佐藤 歩・川越清樹 2009: 温暖化による洪水氾濫とその 適応策. 地球環境, 14 (2), 135-142.

気争庁: 降雨データ, http://www.jma.go.jp/jma/menu/menureport. $\mathrm{html}$ (参照:2016/01/25).

国土交通省: 地理院地図 (電子国土WEB) https://maps.gsi.go.jp/ index.html. (参照:2017/02/14).

国土交通省:国土数值情報, http://nlftp.mlit.go.jp/ksj/. (参照:2017/ 01/16).

国土交通省: 水害統計調査, 2006-2013.

国土交通省: 水害統計調査調査要領 (市区町村用), http://www. mlit.go.jp/river/_sonohoka/flood_ss/index.html. (参照:2016/ 01/25).

国土地理院: 基盤地図情報, https://fgd.gsi.go.jp/download/ menu.php. (参照:2017/02/14).

村山良之 1987 : 都市化に伴う水害常襲地の形成-川崎市の例 東北地理, 39 (3), 147-160.

野々村敦子・鎌田昇悟・長谷川修一・林 宏年 2011: DEMを用いた 内水氾濫危険箇所抽出方法の検討. 土木学会論文集F (安全問 題), 67 (2), 131-136.

大阪市: 公立小・中学校の校地及び学校建物, http://www.city. osaka.Ig.jp/toshikeikaku/cmsfiles/contents/0000179/179912/ 14-10.xIs. (参照:2016/09/16).

大阪市: 内水浸水想定区域図, http://www.city.osaka.lg.jp/kensetsu/ cmsfiles/contents/0000296/296896/soutei.pdf. (参照:2017/ 01/16). 


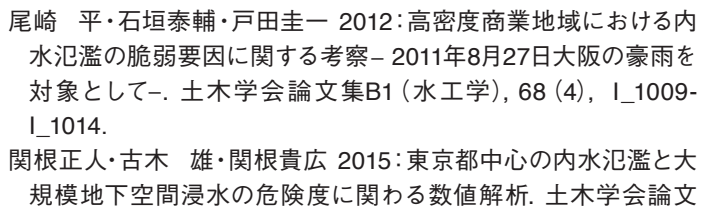

尾崎 平·石垣泰輔·戸田圭一 2012: 高密度商業地域における内 水氾濫の脆弱要因に関する考察-2011年8月27日大阪の豪雨を 対象として-. 土木学会論文集B1 (水工学), 68 (4), I_1009I_1014.

関根正人·古木 雄・関根貴広 2015 : 東京都中心の内水氾濫と大 規模地下空間浸水の危険度に関わる数値解析. 土木学会論文

集, $71(4), 1435-1440$

（受付：2017年2月 15 日，受理：2017年7月 25 日）

この論文への討議・コメントを, 2018年7月末日 まで受け付けます。

\title{
Distribution and Characteristics of Frequent Inland Inundation Areas in Osaka City
}

\author{
Kota NAKAGUCHI $^{1)^{\dagger} \quad \text { Daisuke KOMORI }}{ }^{2)} \quad$ Ryo INOUE $^{3)} \quad$ So KAZAMA ${ }^{4)}$ \\ 1) Graduate School of Engineering, Tohoku University \\ (6-6-6, Sendai, Miyagi, 980-8579, Japan) \\ 2) Graduate School of Environmental Studies, Tohoku University \\ (6-6-6, Sendai, Miyagi, 980-8579, Japan) \\ 3) Graduate School of Information Sciences, Tohoku University \\ (6-6-6, Sendai, Miyagi, 980-8579, Japan) \\ 4) Graduate School of Engineering, Tohoku University \\ (6-6-6, Sendai, Miyagi, 980-8579, Japan) \\ ${ }^{\dagger}$ Corresponding Author E-mail : t657007@st.pu-toyama.ac.jp
}

For this study, we extracted the frequent inland inundation area in Osaka city using maps of flood damage during 1993-2012. The maps were drawn manually for each city as paper-based flood records. Because of the unfixed patterns and methods of drawing the maps, these maps have not been used for flood damage vulnerability analyses. We have translated these paper-based maps into digitized maps on GIS database, and have extracted the frequent inland inundation area. The result of analysis of the extracted area is the following: Frequent inland inundation area tends to be distributed in "plain" than "depression" areas, and sewer construction is conducted predominantly in "depression" areas. The "plain" and "depression" areas are extracted using the flood inundation model. Furthermore, results clarified that the frequent inland inundation area tends to be distributed to the area 1 ) with a small slope or low elevation; 2) around the structure which divides the land surface flow and sewer by such as road and rail; and 3) around the school spacing in a single line.

Key words : inland inundation, metropolitan area, flood area map, GIS 